\title{
CHARACTERISATION AND IN VIVO SAFETY OF CANINE ADIPOSE-DERIVED STEM CELLS ${ }^{*}$
}

\author{
Uldis Bērziṇšs ${ }^{1,3, \#, ~ I l z e ~ M a t i s e-V a n H o u t a n a ~}{ }^{2}$, Ilze Pētersone ${ }^{2}$, Ilmārs Dūrītis ${ }^{2}$, \\ Sergejs N̦ikuḷ̌sinss ${ }^{4}$, Ance Bogdanova-Jātniece ${ }^{1}$, Mārtinš̌ Kālis ${ }^{5}$, Šimons Svirskis ${ }^{5}$, \\ Dace Skrastina ${ }^{1}$, Agnese Ezerta ${ }^{1}$, and Tatjana Kozlovska ${ }^{1}$ \\ ${ }^{1}$ Latvian Biomedical Research and Study Centre, 1 Rātsupītes Str., Rīga, LV-1067, LATVIA \\ ${ }^{2}$ Faculty of Veterinary Medicine, Latvia University of Agriculture, 2 Lielā Str., Jelgava, LV-3001, LATVIA \\ ${ }^{3}$ Stem Cells Technologies Ltd., Rīga, LATVIA \\ ${ }^{4}$ Children's Clinical University Hospital, 45 Vienības gatve, Rīga, LV-1004, LATVIA \\ ${ }^{5}$ Augusts Kirhenšteins Institute of Microbiology and Virology, Rīga Stradinš University, 5 Rātsupītes Str., Rīga, LV-1067, LATVIA \\ \# Corresponding author, uldis@cst.lv
}

Communicated by Tatjana Kozlovska

The study characterises canine adipose-derived stem cells (CASCs) in comparison to human ASCs (hASCs) and tests their safety in a canine model after intravenous administration. cASCs from two dogs were cultured under hypoxic conditions in a medium supplemented with autologous serum. They were plastic adherent, spindle-shaped cells that expressed CD73, CD90, and CD44 but lacked CD45, CD14, HLA-DR, and CD34. CASCs differentiated toward adipogenic, osteogenic, and chondrogenic lineages, although adipogenic differentiation capacity was low. Blast transformation reaction demonstrated that these cells significantly suppress $T$-cell proliferation, and this ability is dose-dependent. Intravenous administration of a cell freezing medium, therapeutic dose of cASCs $\left(2 \times 10^{6}\right.$ live cells $\left./ \mathrm{kg}\right)$, and five times higher dose of cASCs showed no significant side effects in two dogs. Microscopic tissue lesions were limited to only mild, non-specific changes. There were no signs of malignancy. The results of the study indicate that cASCs are similar to hASCs and are safe for therapeutic applications in a canine model. The proposed methodology for ASC preparation on a non-routine basis, which includes individually optimised cell culture conditions and offers risk-adapted treatment, could be used for future personalised off-the-shelf therapies, for example, in myocardial infarction or stroke.

Key words: autologous adipose-derived stem cells, stem cell safety, pulmonary first-pass effect, advanced therapy medicinal products, hospital exemption.

\section{INTRODUCTION}

Regenerative medicine is a rapidly advancing field of research that offers broad possibilities for treating severe diseases resistant to conventional therapies. It is expected that the significance of regenerative medicine will continue to increase in future; it may become one of the main branches of personalised medicine, which offers tailoring of treatments to specific needs, characteristics, and preferences of each patient during every stage of medical care (www.fda.gov). Personalisation of regenerative medicine has already facilitated the emergence of such innovative therapies as advanced therapy medicinal products (ATMPs) that encompass gene and cell therapy as well as tissue engineering (Anonymous, 2014; General, 2015; Vives and Carmona, 2015).
The use of mesenchymal stem cells (MSCs) as ATMP is a promising aspect of regenerative medicine. Since it was demonstrated that MSCs can be readily obtained from adipose tissue (Zuk et al., 2001), fat has become a valuable source of MSCs. These cells are ideally suited for the development of effective cell-based therapies due to their multilineage differentiation ability (Zuk et al., 2002; Desiderio et al., 2013), capacity to migrate to the site of injury (Liu et al., 2012; Li et al., 2013; Karagiannis et al., 2017; Kim et al., 2017) and regenerate damaged tissues (Lim et al., 2013; Tsuji et al., 2014), as well as due to their immunomodulatory potential (Tyndall and Uccelli, 2009; Ghannam et al., 2010; Lo Sicco et al., 2017). Research has shown that adipose-derived stem cells (ASCs) can be used to treat immune disorders, including graft-versus-host disease (Fang et al.,

\footnotetext{
* Supplementary material associated with this article can be found in the online version.
} 
2007; Fang et al., 2009), psoriasis (De Jesus et al., 2016), and multiple sclerosis (Stepien et al., 2016).

ASCs as ATMP can be applied for human therapy in cases of so-called hospital exemptions (HEs), employing personally prepared autologous stem cells. One of the first steps in the applications of such ATMP is to verify the process and to gain experience using animal models. Companion animals, including dogs, naturally develop chronic autoimmune diseases such as atopic dermatitis (Hall et al., 2010), pemphigus (Han et al., 2015), and diabetes mellitus (Abdi et al., 2008; Kim et al., 2017; O'Kell et al., 2017) that are similar to human disorders (Carrade and Borjesson, 2013; de Bakker et al., 2013; Hoffman and Dow, 2016) and could be treated using ASCs. However, before undertaking such treatments, safety tests using laboratory dogs should be performed. The results and knowledge of ASC therapy in dogs can be further used for human treatments.

The International Society for Cellular Therapy has proposed basic criteria that allow identifying MSCs (Dominici et al., 2006), and based on those we have previously characterised human ASCs (hASCs) (Bogdanova et al., 2014; Legzdina et al., 2016). In this study, the same criteria were used to assess canine ASCs (cASCs) in addition to establishing their safety after two intravenous administrations in a canine model. Here, the term 'safety' implies the evaluation of the risk-benefit ratio (Veriter et al., 2015), which was analysed in two stages. In the first stage, a pulmonary first-pass effect was assessed by evaluating blood and urine test results, electrocardiogram, echocardiogram and behaviour to rule out the risk of pulmonary thromboembolism. It is known that after intravenous administration of MSCs, they are initially trapped in the lungs (Fischer et al., 2009; Eggenhofer et al., 2012; Prologo et al., 2016). Intravenous infusion of ASCs is safe (Ra et al., 2011a; Ra et al., 2011b; Kang and Park, 2014), but cryopreserved or freshly thawed cells may cause a potential risk of pulmonary embolism, oedema, and even death (Furlani et al., 2009; Cyranoski, 2010; Jung et al., 2013; Tatsumi et al., 2013; Lysaght et al., 2017). It could be provoked by the aggregate formation in blood vessels as well as the response of the complement and immune system to infused ASCs (Eggenhofer et al., 2014; Moll and Le Blanc, 2015). In the second stage, necropsy of animals and subsequent histomorphological analysis were performed to detect late changes in tissues and exclude the risk of atypical tissue or tumour formation. After a pulmonary first-pass effect, ASCs tend to migrate to the sites of injury/inflammation (Anjos-Afonso et al., 2004; Bentzon et al., 2005; Kraitchman et al., 2005). However, there is not enough evidence showing that after homing to injured tissues ASCs do not show signs of malignisation or form uncharacteristic tissues at the homing site.

The aim of this study was to develop a specific ASC preparation methodology as well as characterise cASCs that were prepared using this methodology and to test their safety in a canine model after intravenous administration. Our methodology included several aspects: a) use of autologous serum (AS) during ASC expansion under hypoxic conditions (5\% oxygen) and cryopreservation; b) exposure of ASCs to two freeze-thaw cycles before intravenous infusion; c) use of freshly thawed ASCs for in vivo administration; and d) autologous application of cultured ASCs.

\section{MATERIALS AND METHODS}

Legal permits for use of animals and cells in research. Animal experiments were done in accordance to standards outlined for ethical use of animals in research approved by the Food and Veterinary Service of the Ministry of Agriculture of the Republic of Latvia (permit No. 23). The dogs were kept and experiments were carried out at the Clinical Institute of the Latvian University of Agriculture, Jelgava, Latvia, by trained veterinary medical professionals. hASCs were isolated from human subcutaneous adipose tissue after consent was obtained from the donor in accordance with permit No. 12 issued by the Latvian Central Medical Ethics Committee. Processing of human and canine adipose tissue, ASC expansion, freezing, and storing took place at Stem Cell Technologies Ltd., Rīga, Latvia. Characterisation of ASCs was performed at the Latvian Biomedical Research and Study Centre, Rìga, Latvia.

Characterisation of experimental animals. Two Beagle dogs were studied, one female and one male. Neither of the animals had been sterilised/castrated. Both animals were obtained from a certified laboratory animal facility CEDS (France). The animals were 2.5 years old at the time of cASC administration and 5 years old at the time of euthanasia. The body weight at the time of cASC administration was $14.5 \mathrm{~kg}$ (female) and $18.5 \mathrm{~kg}$ (male). After euthanasia, the body weight was $17 \mathrm{~kg}$ (female) and $18.4 \mathrm{~kg}$ (male), the body condition was good (3.5 points for a female and 3 points for a male on a 5 point scale).

Animal care and nutrition during the experiments. The animals were kept in heated, insulated $2 \times 1.5 \mathrm{~m}$ box rooms with ventilation. The animal facility had separate rooms for food preparation (kitchen), staff changing, shower, and toilet. All rooms were easy to disinfect and had a separate drainage system. Dry Complex Technical Feed was given twice daily, and fresh water was available continuously. Walking was provided three times daily. Physiological parameters (rectal temperature, respiratory rate, and heart rate) were controlled twice daily; mucous and subcutaneous lymph node examinations were done once daily.

Autologous serum (AS) preparation. Blood was collected as described in the section "Pulmonary first-pass effect" and allowed to clot for $1 \mathrm{~h}$ at room temperature. The serum was collected, centrifuged at $2000 \mathrm{rpm}$ for $30 \mathrm{~min}$, filtered through a $0.2 \mu \mathrm{m}$ mesh, aliquoted, and stored at $-20{ }^{\circ} \mathrm{C}$.

ASC isolation, expansion, and characterisation. Collection of canine adipose tissue. The animals were premedicated by subcutaneous atropine sulphate injection $(0.05$ $\mathrm{mg} / \mathrm{kg}$ ) to reduce the anaesthetic side effects and intramuscular sedative injection $(0.02 \mathrm{mg} / \mathrm{kg}$ acepromazine maleate). 
Intravenous injection of ketamine hydrochloride $(6 \mathrm{mg} / \mathrm{kg})$ and diazepam $(0.6 \mathrm{mg} / \mathrm{kg})$ was administered for a temporary anaesthesia.

To prepare the skin for surgery, a $15 \times 15 \mathrm{~cm}$ area of hair from the right caudoventral quadrant of abdominal wall was shaved, followed by washing with soap, disinfection with $70 \%$ alcohol three times and disinfection with iodine alcohol solution three times.

An incision $5 \mathrm{~cm}$ in length, parallel to the body's longitudinal axis (medial plane) 5-7 cm laterally from the white line was made in the skin layer. Subcutaneous fat was obtained by cutting an about $5 \mathrm{ml}$ piece of tissue with scissors. After that sutures were placed in the subcutis (Safil, Aesculap, USA) and the skin (Supramid, S. Jackson, Inc., Unites States). Post-operative care of the animals consisted of continuous monitoring of the physiological parameters during the surgery and $2 \mathrm{~h}$ after the end of the anaesthetic effect as well as daily maintenance of the surgical wound until complete healing.

ASC extraction and expansion. The method of ASC isolation has been described previously for hASCs (Bogdanova et al., 2014; Legzdina et al., 2016). Briefly, $5 \mathrm{ml}$ of the collected adipose tissue was scissored and treated with $0.3 \%$ pronase (EMD Millipore, USA) for $1 \mathrm{~h}$ at $+37{ }^{\circ} \mathrm{C}$ and centrifuged for $7 \mathrm{~min}$ at $1000 \mathrm{rpm}$. The obtained cell pellet was suspended, filtered through a $40 \mu \mathrm{m}$ mesh membrane, and centrifuged again for 5 minutes. Erythrocytes were lysed for 3 min at $+37{ }^{\circ} \mathrm{C}$ using erythrocyte lysis buffer Hybri-Max (Sigma-Aldrich, Germany). The cell pellet was suspended in a fresh cell culture medium DMEM/F12 (Life Technologies, United Kingdom) containing 10\% AS, $2 \mathrm{mM}$ L-glutamine (Life Technologies, United Kingdom), 20 $\mathrm{ng} / \mathrm{ml}$ basic fibroblast growth factor (BD, USA), and 100 $\mathrm{U} / \mathrm{ml}: 100 \mathrm{~g} / \mathrm{ml}$ penicillin-streptomycin (Life Technologies, United Kingdom) and seeded onto a $75 \mathrm{~cm}^{2}$ tissue culture flask (regarded as passage $0(\mathrm{P} 0)$ ). At all steps, ASCs were cultured at $+37{ }^{\circ} \mathrm{C}, 5 \% \mathrm{CO}_{2}$, and $5 \% \mathrm{O}_{2}$ in a hypoxic workstation (Xvivo System, Biospherix, USA).

Non-adherent cells were removed on the day after seeding by extensive washing with phosphate-buffered saline (PBS) (Life Technologies, United Kingdom). The remaining cells were cultured in a medium containing $10 \%$ AS for the first ten days and 5\% AS thereafter. At the end of P1, the cells were frozen in DMEM/F12 supplemented with $10 \%$ dimethyl sulfoxide (DMSO) (Sigma-Aldrich, Germany) and $20 \%$ AS and stored in liquid nitrogen. After at least three months of storage, ASCs were thawed and cultured as previously through P2 to P5, freezing the propagated ASCs at the end of P5 for the second time. After at least three months of storage, ASCs from P5 were thawed and used for the subsequent characterisation.

Multicolour flow cytometry. Flow cytometry analysis of cASCs was performed using freshly thawed cells from P5 according to a conventional protocol (Shapiro and Shapiro, 2003). Briefly, the thawed cells were washed with PBS and resuspended at a concentration of $5 \times 10^{6} \mathrm{cells} / \mathrm{ml}$. The cells were tested for viability using a $0.5 \mu \mathrm{M}$ cell-permeant fluorescent Syto16 nucleic acid stain (Life Technologies, UK), separating live (positive) cells from apoptotic cell population on the FITC channel (Sparrow and Tippett, 2005). cASCs were further tested for aneuploidy and mitotic activity, using a PI-based Cycletest Plus DNA kit and the ModFit software (Becton-Dickinson, USA).

Two paired samples where used for phenotyping. The first sample was stained with antibodies to CD90 (APC, eBioscience, USA, clone YKIX337.217), CD44 (PerC-Cy5.5, Exbio, Czech Republic, clone IM7), CD73 (Pe-Cy7, eBioscience, USA, clone AD2), and CD34 (PE, Exbio, Czech Republic, clone 1H6) and an antibody cocktail to CD45 (FITC, eBioscience, USA, clone YKIX716.13), CD14 (FITC, eBioscience, USA, clone 61D3), and HLA-DR (FITC, eBioscience, USA, clone L243). The second sample was stained with corresponding isotypic control antibodies. The cells were incubated in the dark for $30 \mathrm{~min}$, washed, resuspended in PBS, and analysed within two hours. The analysis was performed using a BD FacsCanto II flow cytometer (Becton Dickinson, USA) with standard 3-laser configuration; at least 10000 events were acquired in each sample. The Infinicyt software (Cytognos S.L., Spain) was used for data analysis and image generation.

Trilineage differentiation of ASCs. Methods for in vitro adipo-, osteo- (Legzdina et al., 2016), and chondrogenic (Bogdanova et al., 2014) differentiation of ASCs using human ASCs have been described previously. In this study, we employed the same methods for cASCs, using hASCs as a control. Differentiation of ASCs was performed at P6 (after thawing the cells from P5 and seeding them).

Co-culture of cASCs and autologous PBMNCs (blast transformation). The method for blast transformation has been described previously (Bogdanova et al., 2014). Briefly, autologous peripheral blood mononuclear cells (PBMNCs) were obtained from freshly isolated peripheral blood samples using a Ficoll-Paque Premium density gradient (GE Healthcare, Uppsala, Sweden). PBMNCs were cultured in RPMI-1640 medium (Life Technologies, United Kingdom) supplemented with $10 \%$ AS, 2 mM L-glutamine and 100 $\mathrm{U} / \mathrm{ml}: 100 \mathrm{~g} / \mathrm{ml}$ penicillin-streptomycin in the presence of cASCs (P6) at different ratios (cASCs:PBMNCs $-5 \times 10^{4}$ $: 5 \times 10^{4}(1: 1), 5 \times 10^{3}: 5 \times 10^{4}(1: 10), 2.5 \times 10^{3}: 5 \times$ $10^{4}(1: 20), 1.25 \times 10^{3}: 5 \times 10^{4}(1: 40), 5 \times 10^{2}: 5 \times 10^{4}$ (1 : 100)) and phytohemagglutinin (Sigma-Aldrich, Germany) at a final concentration of $2 \mu \mathrm{g} / \mathrm{ml}$ for $96 \mathrm{~h}$ at $+37{ }^{\circ} \mathrm{C}$, $5 \% \mathrm{CO}_{2}$. Then $1 \mu \mathrm{Ci}$ of $[3 \mathrm{H}]$-deoxythymidine (GE, United Kingdom) was added to each well for the last 18 hours. Analysis of radioactive thymidine incorporation was done using a liquid scintilation beta counter (Beckman Coulter, USA).

Autologous cASC administration. Prior to cephalic vein catheterisation, premedication with an intramuscular injection of acepromazine maleate $(0.5 \mathrm{mg} / \mathrm{kg})$ for sedation of the animal was administered. The puncture area was pre- 
pared as follows: a $5 \times 5 \mathrm{~cm}$ area of the cephalic groove was shaved, and the skin was disinfected with $70 \%$ alcohol $(3 \times)$ and iodine alcohol solution $(1 \times)$. An aseptic puncture of the external cephalic vein with a G18 needle was performed, and a catheter was attached using leucoplast tape and a bandage.

First, to evaluate the potential side-effects of a DMSO (control medium) and to describe its excretion, $100 \mathrm{ml}$ of physiological saline containing 10\% DMSO was injected intravenously. Second, a therapeutic dose of $2 \times 10^{6}$ live, freshly thawed, non-washed autologous cASCs (P5) per kg of body weight in a total volume of $100 \mathrm{ml}$ (adjusted with a physiological saline) was administered to the experimental dogs. Third, a five times higher dose of cASCs $\left(1 \times 10^{7}\right.$ live cells $/ \mathrm{kg}$ ) was intravenously injected one month later.

Pulmonary first-pass effect. Assessment of dogs' behaviour. In order to evaluate the dogs' behaviour, partial behavioural assessment tests were performed before and after intravenous administration of DMSO medium and cASCs. A sociability test was used to determine dog's behaviour in a room by evaluating body postures, sniffing, exploring, eye contact, and social contact with humans. A teeth exam was employed to test dog's response to teeth and mouth inspection for five seconds. A handling test was used to evaluate dog's response to touching and stroking of various body parts for five seconds, including the tail and the ears.

Blood and urine sample collection. To collect blood samples, the premedication and preparation of the puncture area were performed as described in section 2.6. A G16 needle was used and $50 \mathrm{ml}$ (but no more than $0.5 \%$ of body weight) of blood was collected.

Urine and blood samples were collected $24 \mathrm{~h}$ before and 12 , 24 , and $72 \mathrm{~h}$ after the infusion of DMSO medium as well as $24 \mathrm{~h}$ before and $24 \mathrm{~h}, 72 \mathrm{~h}, 7$ days, and 14 days after the administration of cASCs. Blood samples were collected from $v$. jugularis or $v$. saphena into vacutainers with serum stabiliser (for biochemical tests), EDTA (for hematological and morphological characterisation) or sodium citrate (for determination of coagulation factors) (Becton Dickinson, USA). Morning urine mid-stream samples were collected, stored at $+4{ }^{\circ} \mathrm{C}$ and examined up to $3 \mathrm{~h}$ after collection.

Determination of haematological, biochemical, and coagulation factors. Biochemical tests were performed with an Ortho Vitros DT60/DTEII/DTSC analyser (Ortho Clinical Diagnostics, USA) using a disposable slide colorimetric assay. Biochemical blood tests were also performed at the certified (accreditation certificate No. LATAK-M-43400-2011) company's "Centrālā laboratorija” Ltd. laboratory (Reg. No. $215 /$ L 430-C) by standard laboratory protocols in compliance with LVS NE ISO 15189:2008 standard.

Blood haematological examinations were run automatically using a Nihon Kohden MEK 6318 K analyser (Nihon Kohden, Japan) and morphological examinations were performed by evaluating blood smears on a binocular micro- scope Omax at magnification of 40-2000× (Omax, South Korea).

Coagulation factors were determined one day before and one day after a single infusion of $10 \%$ DMSO as well as before both administrations of cASCs. Blood samples for coagulation factor determination were collected in tubes with $3.8 \%$ sodium citrate; plasma was centrifuged, frozen at $-20{ }^{\circ} \mathrm{C}$, and sent to the IDEXX Vet Med Laboratory (IDDEXX GmbH, Germany) for analyses. The following coagulation factors were tested: prothrombin time (PT), activated partial thromboplastin time (aPTT) and fibrinogen. Their normal values were: aPTT $<13.5 \mathrm{~s}$; fibrinogen $1.2-2.9 \mathrm{~g} / \mathrm{l}$; prothrombin time seconds.

Urine samples were analysed by Combi-Screen Vet 11 Plus test strips (Analyticon, Germany), recording the result $60 \mathrm{~s}$ after application. Urine density was determined using a refractometer. Urine samples were centrifuged at $3500 \mathrm{rpm}$ for $10 \mathrm{~min}$, and urine sediments were examined for leukocytes, erythrocytes, epithelial cells, bacteria (number/HPF), crystals and cylinders (number/LPF) using a binocular microscope Omax at magnification of 40-2000x.

Cardiac monitoring. Electrocardiographic examination was performed $24 \mathrm{~h}$ before and 3, 7, and 14 days after both cASC infusions. Echocardiography was performed $24 \mathrm{~h}$ before and three days after the administrations of cASCs. Additionally, continuous Holter monitoring was performed $24 \mathrm{~h}$ prior to the administrations of cASCs as well as during the first $24 \mathrm{~h}$ after both cASC infusions.

Electrocardiographic examinations were performed with a BTL-08 apparatus (BTL Industries, Inc., USA) while the animals were sleeping on the right lateral side. Six leads (I, II, III, aVR, aVL, aVF) were obtained. Data were saved and processed using the BTL software (BTL Industries, Inc., USA). The electrocardiogram was used to analyse the heart rhythm: primary rhythm transmitter specified (sinoatrial node, sinus rhythm) and heart rate. The II-lead was used for P-QRS-T analysis.

Echocardiographic examinations were performed with an ultrasound scanner Philips HD-11 (Philips, the Netherlands) while the animals were sleeping on the right lateral side to obtain right-side parasternal proximal and transverse projections of the heart and on the left lateral side to obtain leftside parasternal apical projections. Standard measurements of the left ventricle in systole and diastole (M mode), visual assessment of the right ventricle and the atrium, left atrial and aortic measurements (in 2D mode), and dopplerographic examination with the determination of transmitral and transtricuspid blood flow (PW dopplerography) and aortic and pulmonary arterial blood flow (CW dopplerography) were performed.

For Holter monitoring, we used a Televet 100 system (Telvet, Germany), attaching electrodes to the animal's chest. Standard leads I, II, and III were obtained. The obtained data were analysed using Televet 100 software. The cardiac 
rhythm was analysed from the electrocardiogram. The primary rhythm pacemaker (sinoatrial node), the average heart rate at each monitoring hour, and the maximum and minimum heart rates were determined.

Euthanasia, necropsy, and histological examination. The animals were sacrificed using euthanasia solution T-61 (0.3 $\mathrm{ml} / \mathrm{kg}$ ), which contained $200 \mathrm{mg}$ embutramide, $50 \mathrm{mg}$ mebezoniumiodide, and $5 \mathrm{mg}$ tetracaine hydrochloride in $1 \mathrm{ml}$ of the solution. The euthanasia solution was administered intravenously after intramuscular sedative injection $(0.02$ $\mathrm{mg} / \mathrm{kg}$ acepromazine maleate) and intravenous injection of anaesthetic agents ketaminum $(4 \mathrm{mg} / \mathrm{kg})$ and diazepam $(0.4$ $\mathrm{mg} / \mathrm{kg})$.

Necropsy was done 30 min after euthanasia; bodies of dogs subjected to necropsies were in excellent post-mortem condition. No muscle stiffness or autolysis were observed. Hair, skin, and nails were clean. In the female dog, outer body orifices were clean and without excretions. In the male dog, anus was open, stained with dry feces; the rest of the outer orifices were clean and without excretions. The female dog had minor hypostasis on the right side.

Representative samples of animal tissues and organs were collected and fixed in $10 \%$ formalin (Sigma-Aldrich, Germany) for at least $24 \mathrm{~h}$. Smaller sections were trimmed for embedding in paraffin. After tissue dehydration with ascending grades of ethanol, samples were embedded in paraffin and sectioned in $4 \mu \mathrm{m}$ thickness. Obtained tissue sections were stained with haematoxylin and eosin and analysed using a microscope Nicon or Olympus BX51.

Statistical analysis. Comparison of means between different groups was performed using One-Way Analysis of Variance (ANOVA). Brown-Forsythe and Bartlett's tests were applied to study whether the collected data were normally distributed. Between-subjects and intra-subjects differences among groups were assessed with ordinary two-way ANOVA followed by a post-hoc test. In all cases, two-stage step-up method of Benjamin, Krieger, and Yekutieli was used as the post-hoc analysis. $p$ values less than 0.05 were considered as statistically significant. Graphs, calculations, and statistical analyses of blast transformation data were obtained using GraphPad Prism software version 7.0 for Mac (GraphPad Software, USA). Results were represented as the mean \pm SD.

\section{RESULTS}

In vitro characterization of cASCs. Morphology of cASCs. Similarly to hASCs, isolated cASCs were plasticadherent and exhibited typical spindle-shaped morphology. These characteristics of MSCs were affected neither by the use of a cell culture medium that contained AS instead of foetal bovine serum, nor cell culturing under $5 \%$ oxygen. cASCs preserved their fibroblast-like morphology until P6 and after two freeze-thaw cycles (Fig. 1).
Characterisation of cASC surface markers. Multicolour flow cytometry (Fig. 2) of both cell cultures demonstrated a phenotypically homogenous cASC population that was strongly positive for MSC markers CD44 and CD73, intermediately positive for CD90 and negative for hematopoietic stem cell marker CD34 and a cocktail of leukocyte lineage

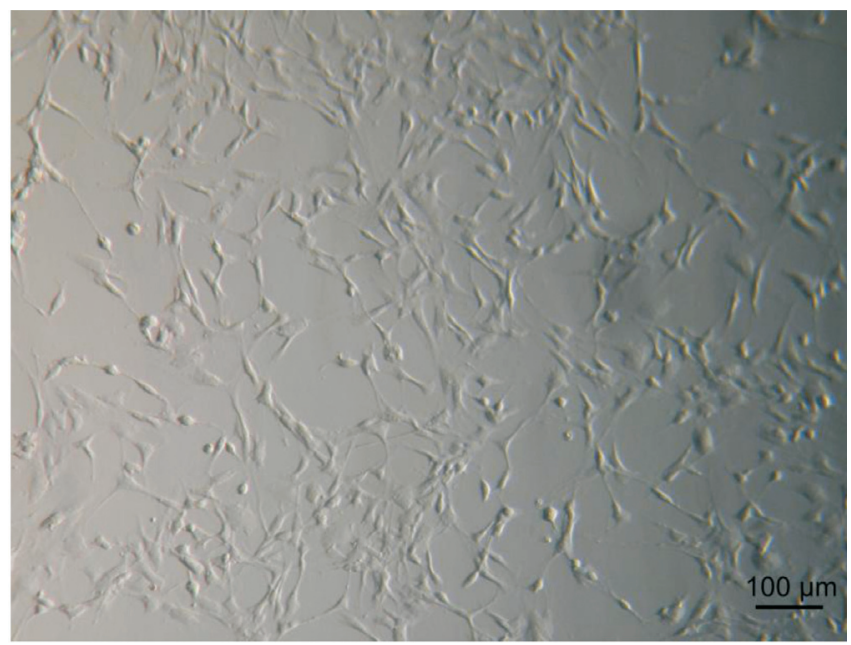

Fig. 1. Morphology of canine adipose-derived stem cells at passage 6 . Scale bar $100 \mu \mathrm{m}$.
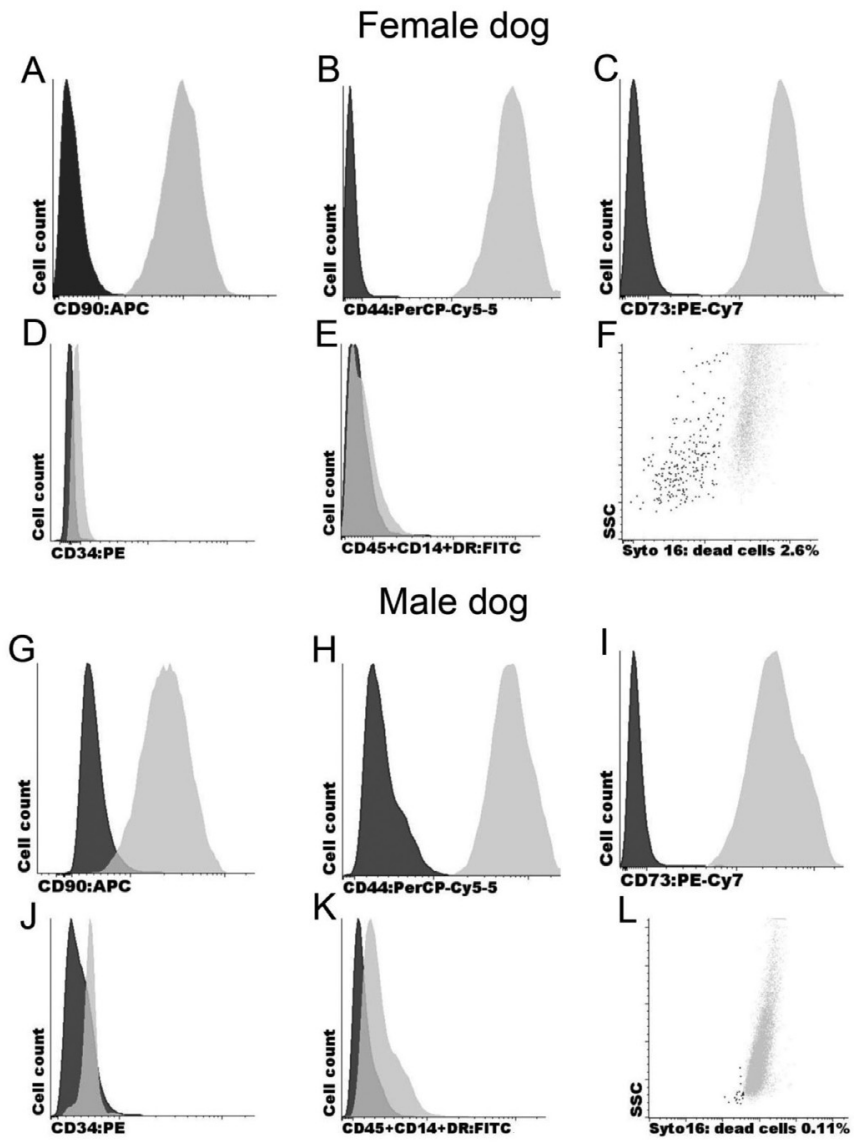

Fig. 2. Phenotypic analysis of freshly thawed canine adipose-derived stem cells at passage 5 using multicolour flow cytometry. (A-E, G-K) Expression of cell surface markers CD90, CD44, CD73, CD34, CD45, CD14, and HLA-DR (dark peak - isotype control, light peak - specific staining). (F, L) Syto 16 cell viability stain (dark dots - apoptotic cells, light dots - live cells). 
antigens CD45, CD14, and HLA-DR, thus complying to MSC criteria (Dominici et al., 2006).

Syto16 staining showed that the proportion of apoptotic cells was below $5 \%$ in both samples (Fig. 2 F, L), indicating good cell viability. DNA staining detected no aneuploidy; the PI-defined proliferating fraction $(\mathrm{S}+\mathrm{G} 2)$ was $2.97 \%$ in the male dog and $6.91 \%$ in the female dog.

Trilineage differentiation of the ASCs. To assess in vitro differentiation potential of cASCs, the cells from P6 were differentiated toward adipogenic, chondrogenic, and osteogenic lineages. In parallel, hASCs, also from P6, were subjected to the same differentiation protocols serving as a positive control. The obtained results showed that both cASCs and hASCs possess similar chondrogenic and osteogenic differentiation potential. Alcian Blue staining of chondrogenic differentiation (Fig. $3 \mathrm{C}, \mathrm{H}, \mathrm{K}$ ) confirmed the presence of sulfated glycosaminoglycans, characteristic to the extracellular matrix of chondrocytes, and cartilage-like lacunae structures. Calcium deposits within mineralised extracellular matrix produced by differentiated osteoblasts were detected by Alizarin Red S staining of osteogenic differentiation (Fig. 3 E, I, L). Adipogenesis was assessed using the Oil Red $\mathrm{O}$ stain of adipogenic differentiation (Fig. 3 A, G, J). Although cASCs demonstrated the potential to differentiate into adipocytes, it was highly reduced compared to hASCs. Only a few cASCs showed accumulation of intracellular lipid droplets, despite their altered morphology. Both cASCs and hASCs exhibited no signs of adipogenic or osteogenic differentiation in control media, except for a faint blue staining observed in the chondrogenic control medium. As an example, only the results of cASCs in the control medium from the female dog are shown here (Fig. $3 \mathrm{~B}$, $\mathrm{D}, \mathrm{F})$.

Immunosuppressive properties of cASCs. To test the effect of cASCs on PBMNC proliferation, cASCs were cocultured with autologous, phytohemagglutinin (PHA)-stimulated PBMNCs. Non-stimulated PBMNCs served as a negative control, and PHA-stimulated PBMNCs were used as a positive control. cASCs demonstrated a statistically

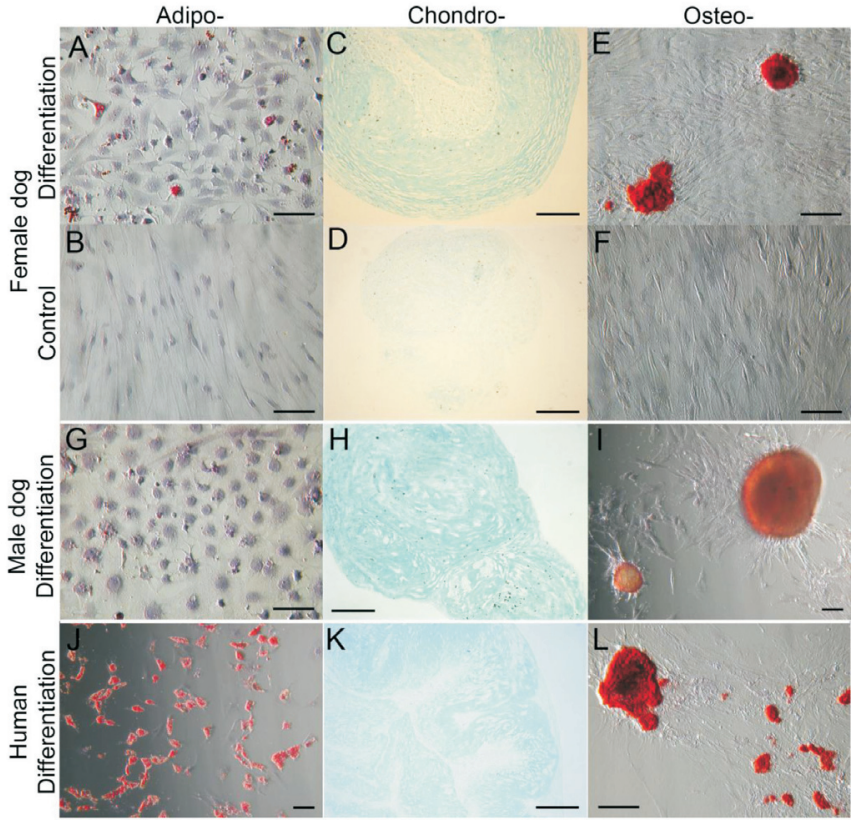

Fig. 3. In vitro differentiation of canine and human adipose-derived stem cells toward adipogenic, chondrogenic, and osteogenic lineages. (A, G, J, and B) Oil Red O staining of differentiated and control cells. The cells were counterstained with haematoxylin. (C, H, K, and D) Alcian Blue staining of differentiated and control cells. (E, F, L, and I) Alizarin Red S staining of differentiated and control cells. Scale bar $100 \mu \mathrm{m}$.

significant reduction of $\mathrm{PBMNC}$ proliferation when the cASC:PBMNC ratio reached 1: 40 or less (Fig. 4 A). The observed immunosuppressive effect of cASCs was dose dependent, reaching its peak at cASC : PBMNC ratio $1: 1$. We found the same tendency in tests using hASCs (Bogdanova et al., 2014), and the regression analysis of cASC and hASC immunosuppressive ability confirmed their similarity (Fig. 4 B).

Evaluation of a pulmonary first-pass effect. Animal behaviour. Before and after intravenous administrations of cASCs as well as $10 \%$ DMSO solution, animal behaviour was evaluated to assess the pulmonary first-pass effect. The sociability test showed that both dogs remained calm with
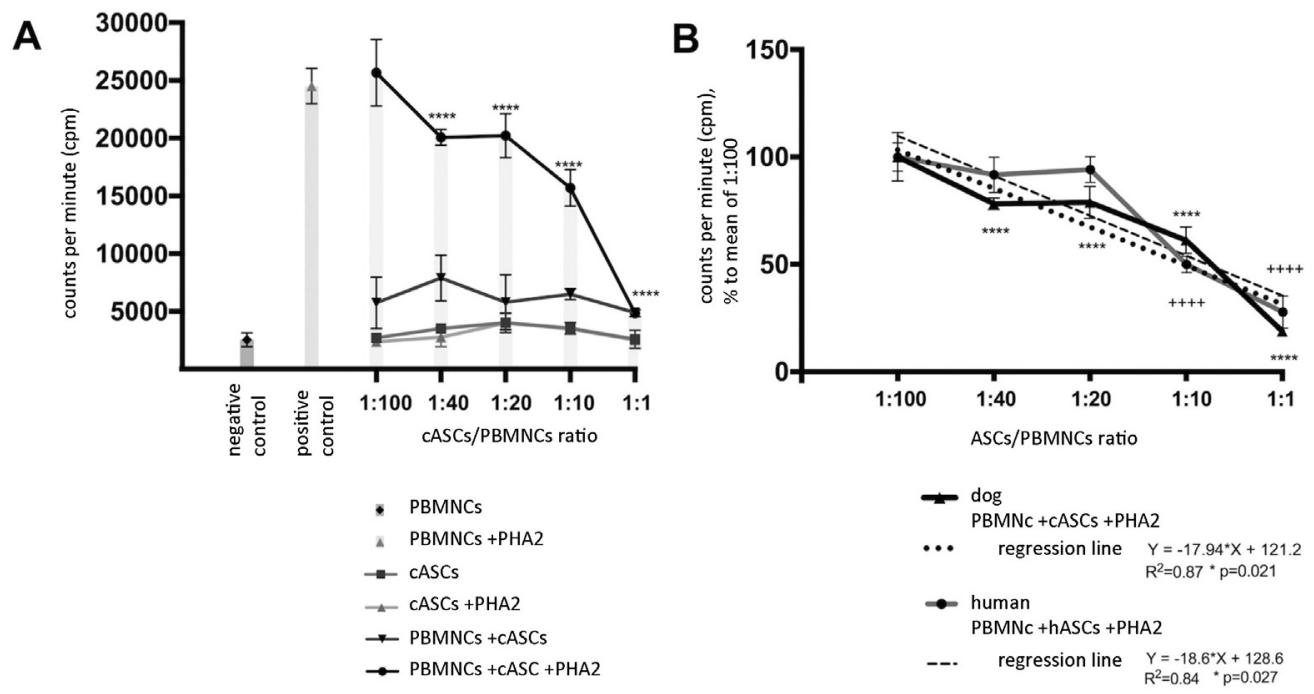

Fig. 4. Co-culture of adipose-derived stem cells (ASCs) and autologous peripheral blood mononuclear cells (PBMNCs). (A) The suppressive effect of canine ASCs (cASCs) from passage 6 on the proliferation of PHA-stimulated PBMNCs in vitro. The results are expressed as counts per minute. (B) Comparison of immunosuppressive ability of cASCs and human ASCs (hASCs). Data represent mean $\pm \mathrm{SD}$ of triplicates. Asterisk indicates statistically significant difference when compared to the PHA-stimulated PBMNCs; $* * * * p<0.0001$ (cASCs); $++++p<0.0001$ (hASCs); PHA2 phytohemagglutinin at a final concentration of $2 \mu \mathrm{g} / \mathrm{ml}$. 
relaxed body postures. They sniffed and explored examination and procedure rooms and made an eye contact as well as calm social contact with humans. Both dogs allowed teeth examination for five seconds without struggle. Similarly, they did not avoid stroking and touching of various body parts, including the tail and the ears, for at least five seconds. Throughout the procedures, the animals remained calm, and the administrations of cASCs or DMSO did not provoke any changes in the above-mentioned animal behaviour.

Blood and urine tests. No significant alterations in the blood and urine test results were observed after 10\% DMSO infusion.

Similarly, blood tests were normal after the administration of a therapeutic cASC dose $\left(2 \times 10^{6}\right.$ live cells $\left./ \mathrm{kg}\right)$, except for total blood bilirubin level in the female dog which was $25 \mu \mathrm{mol} / \mathrm{l}$ (normal range is $0-10.20 \mu \mathrm{mol} / \mathrm{l}$ ) $24 \mathrm{~h}$ after the cASC administration and $11 \mu \mathrm{mol} / \mathrm{l}$ three days after the cell infusion (Fig. 5). Urine tests showed that urine bilirubin and urobilinogen levels were elevated, bilirubin being rated as ++ (norm: +) and urobilinogen $140 \mu \mathrm{mol} / \mathrm{l}$ (norm: 3.5 $\mu \mathrm{mol} / \mathrm{l}) 24 \mathrm{~h}$ after the cASC infusion in the female dog. The urine bilirubin levels remained slightly elevated also three and seven days after the cASC administration. The blood and urine bilirubin levels were normal at all time points in the male dog.

After the second administration of a five times higher cASC dose $\left(1 \times 10^{7}\right.$ live cells $\left./ \mathrm{kg}\right)$ one month later, the blood and urine test results were normal, except for urine bilirubin levels which were elevated $24 \mathrm{~h}$ and three days after the cASC administration in the female dog.

Electrocardiography and echocardiography. Electrocardiographic and echocardiographic parameters did not show any deviations from the norm either before or after both cASC administrations. During the procedure, episodes of transient, supposedly stress-induced, sinus tachycardia were observed, which were detected mainly during the manipulation and animal fixation. In Holter monitoring (Fig. 6), we did not detect ectopic rhythm disturbances that could indicate myocardial damage.

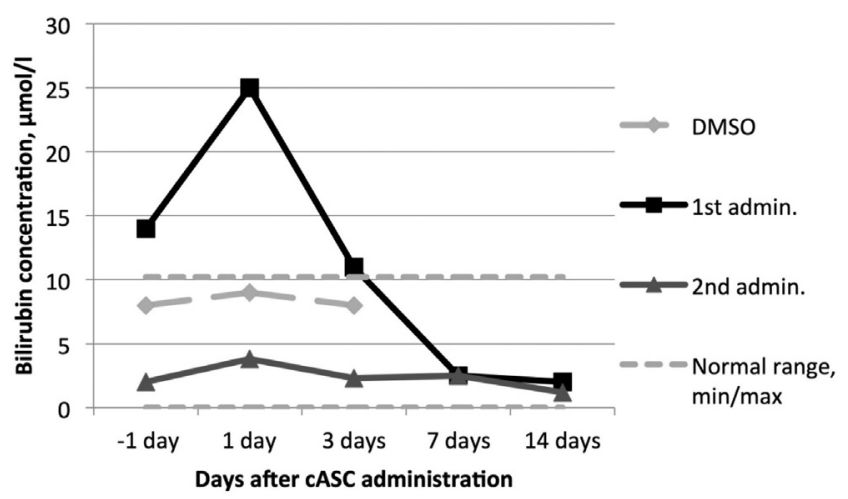

Fig. 5. Blood total bilirubin levels after intravenous administration of $10 \%$ dimethyl sulfoxide (DMSO), the therapeutic dose $\left(2 \times 10^{6}\right.$ live cells $\left./ \mathrm{kg}\right)$ of canine adipose-derived stem cells (cASCs) ( $1^{\text {st }}$ admin.), and the five times higher dose $\left(2^{\text {nd }}\right.$ admin. $)$ in the female dog.
Histomorphological findings. Histomorphological analysis of the animal organs and tissues more than two years after the cASC administration is described in detail and illustrated in the Supplementary material (available in the online version of this paper). Briefly, only minor and relatively non-specific alterations were found in the tissues, and they might be unrelated to cASC administration. No significant side effects, undesirable events or signs of malignancy were detected.

\section{DISCUSSION}

Specifics of the ASC preparation methodology. In accordance with Article 28 of Regulation (EC) 1394/2007 on ATMPs (Anonymous, 2007), in cases of HEs, ATMPs (e.g., ASCs) are prepared on a non-routine basis and according to each manufacturer's specific methodology. In this case, "non-routine" is understood as an enhancement of ASC preparation process in real time and a target for personalised and risk-adapted treatment. An overview of our ASC preparation protocol is shown in Figure 7. Our methodology is designed to obtain ASCs that are processed and altered as little as possible, since they are cryopreserved after P1 and stored for personalised regenerative therapy in the future. When storing ASCs for future applications, it is crucial to freeze them at the earliest passage possible. Demand for the storage of young, healthy, non-aged stem cells is becoming more widespread, and the rapid development and improvement of cell processing technologies makes it possible to

A A Female dog

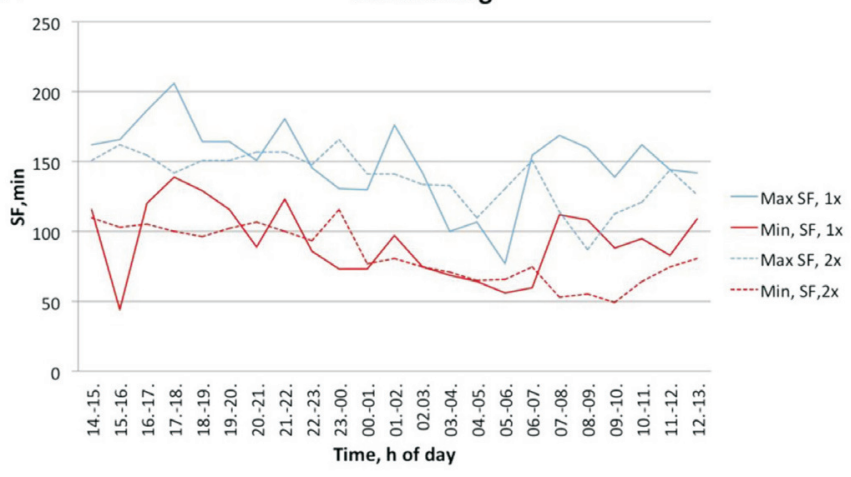

B

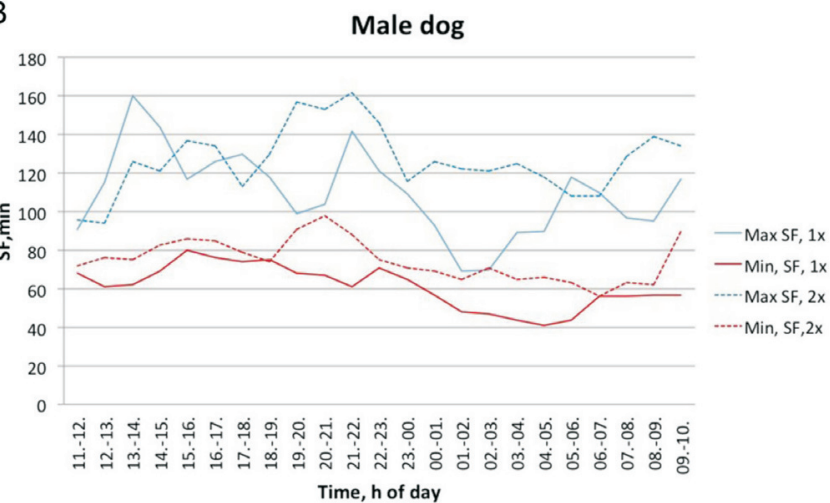

Fig. 6. Heart rate analysis during $24 \mathrm{~h}$ Holter monitoring after intravenous administration of the therapeutic dose $\left(2 \times 10^{6}\right.$ live cells $\left./ \mathrm{kg}\right)$ of canine adipose-derived stem cells $(1 \times)$ and the five times higher dose $(2 \times)$. SF - systolic frame. 


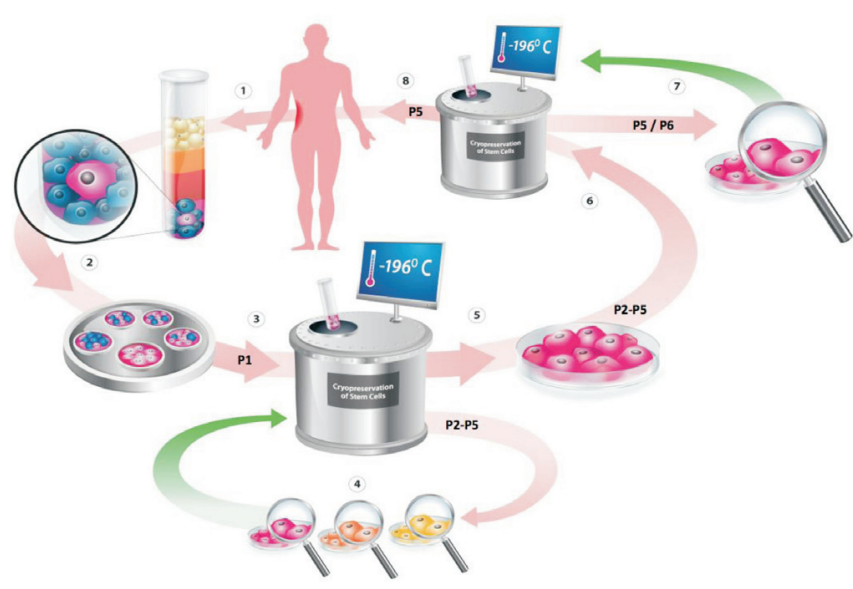

Fig. 7. Manufacturing process of donor-specific adipose-derived stem cells (ASCs). 1. Patient recruitment. 2. Acquisition of adipose tissue and isolation of ASCs. 3. Cryopreservation of ASCs after the first cell passage and their long-term storage. 4. Analysis of ASCs and personalized optimisation of cell culture conditions. 5. Thawing of cryopreserved ASCs and patient-specific ASC propagation based on individually optimised protocol. 6. The second freezing of ASCs prepared for therapy. 7. Additional analysis of propagated ASC batch. 8. Personalized ASC administration to the patient.

store small amounts of processed cells. Therefore, we have chosen to cryopreserve ASCs already after the P1.

Taking into account differences between donors and heterogeneity of stem cell subpopulations (Legzdina et al., 2016; Muzes and Sipos, 2016), resulting in donor-specific cell growth, it is highly important to employ a personalised and individually adapted protocol for ASC preparation. We introduce a novel approach for the propagation and examination of stem cells from different patients on a non-routine basis. We used ASCs from P2 to P5 for a personalised optimisation of cell culture conditions and media composition, which are tested between the first and the second freezing. This allows to identify the most suitable protocol for each individual, thus improving efficiency and safety of the cell product. Therefore, an individually optimised cell culturing protocol can be used for the preparation of a therapeutic ASC dose at the next step of production. In this study, we evaluated the standard method for ASC culturing, which included the use of autologous serum and hypoxic conditions (5\% oxygen), and it will serve as a control method in the future for comparison to optimised cell culture conditions.

When optimal ASC culture conditions have been found for each individual, the cryopreserved cells can be thawed and effectively expanded if a clinical need for the patient emerges. After personalised ASC propagation, the cells are frozen again for the following reasons: a) additional time is needed to test the particular cell lot before administration; b) the planned time of the ASC therapy may be delayed; c) ASC expansion can be performed remotely if a specialised cell laboratory is not available at a medical institution. Such personalised methodology for ASC preparation offers a prospect for the treatment of conventional therapy-resistant diseases as well as improvement of quality of life at older age by using freshly thawed ASCs as a personalised off- the-shelf therapy, for example, in cases of myocardial infarction or stroke (Honmou et al., 2011; McIntosh et al., 2013). Our novel approach to enhance the preparation process of ASCs in real time goes beyond the standard manufacturing process and offers a personalised and risk-adapted treatment in compliance with good manufacturing practices.

Characteristics of cASCs. In this study we demonstrated that MSCs can be readily obtained from canine adipose tissue, and their characteristics are similar to hASCs. The results confirmed that cASCs exhibit characteristic spindleshaped morphology, which has been observed previously (Neupane et al., 2008; Vieira et al., 2010; Martinello et al., 2011), and can be easily propagated in vitro using autologous serum in a cell growth medium. After five cell passages, they represented a phenotypically homogenous ASC population that was positive for typical MSC markers such as CD90, CD44 and CD73 but lacked the expression of CD34, CD45, CD14, and HLA class II. Comparable surface marker expression patterns of cASCs have been described previously (Vieira et al., 2010; Kisiel et al., 2012; Martinello et al., 2011; Reich et al., 2012; Russell et al., 2016; Takemitsu et al., 2012). Most of the previous studies have detected consistent expression of CD90 and CD44 in addition to other positive surface markers, but the expression of CD73 varies across the studies. While some reports have shown moderate CD73 expression (Russell et al., 2016), others have failed to detect it (Vieira et al., 2010; Takemitsu et al., 2012). Similarly, the majority of studies have found no expression of CD45 in cASCs, but mild expression of CD14 and CD34 has been detected (Vieira et al., 2010; Russell et al., 2016). This discrepancy could be explained by different harvest sites of adipose tissue (Sullivan et al., 2016) or variation in antibodies used for the analysis.

Similarly to hASCs, cASCs can differentiate toward chondrogenic, osteogenic, and adipogenic lineages, although their ability to differentiate into adipocytes was very low. The same tendency has been reported before (Vieira et al., 2010), but the optimisation of the induction protocol has improved adipogenic differentiation (Neupane et al., 2008). We have also tried to revise our differentiation protocol accordingly, but it failed to promote cASC differentiation into adipocytes (data not shown). Since cASC multilineage differentiation was performed at P6, this could also explain the weak adipogenic differentiation. Our previous studies using hASCs have shown a similar tendency. We have observed a decline in adipogenic and osteogenic differentiation potential in later hASC passages, and this characteristic was donor-specific (Bogdanova et al., 2014; Legzdina et al., 2016). It is possible that the same applies to cASCs.

Clinical interest in MSCs has been facilitated by their immunomodulatory abilities and inhibitory effect on $\mathrm{T}$ cell as well as B cell proliferation (Di Nicola et al., 2002; Le Blanc et al., 2003; Corcione et al., 2006). Our data from co-culture of cASCs and autologous PBMNCs demonstrated that cASCs suppress proliferation of PBMNCs in a dose-dependent manner, reaching the most effective reduc- 
tion of PBMNC proliferation at a ratio $1: 1$, similarly to hASCs. Other studies have also shown immunosuppressive ability of cASCs (Kang et al., 2008; Russell et al., 2016), and this immunomodulatory effect is partially mediated by soluble factors (Kang et al., 2008). This immunosuppressive ability of ASCs may have a significant therapeutic potential in treating numerous immunological disorders both in humans and dogs.

Overall characteristics of cASCs verified their conformance to MSC criteria (Dominici et al., 2006) and showed their resemblance to hASCs.

In vivo safety of cASCs. In order to increase the safety of ASCs, our methodology included the use of autologous serum instead of conventional foetal bovine serum during ASC expansion and cryopreservation. This helped to eliminate the risk of contamination with foreign proteins that could lead to a possible autoimmune reaction against a patient's own stem cells (Spees et al., 2004). Additionally, to increase the chances of survival of in vitro expanded MSCs after administration, it is important to minimise the differences between conditions in a cell culture and the site of implantation. Since virtually all cell cultures are maintained under atmospheric oxygen concentration $(21 \%)$, but oxygen concentration in tissues can vary between $4-14 \%$ in the well irrigated organs and $0-4 \%$ in bone marrow (Ivanovic, 2009), implanted MSCs can encounter a massive hypoxic stress leading to apoptosis. Therefore, our methodology involves ASC expansion under 5\% oxygen to provide an environment more similar to in vivo conditions and to minimise cell stress. Previous research has shown that MSCs cultured under hypoxic conditions display enhanced ability to repair infarcted myocardium due to the lower cell death and increased angiogenesis ( $\mathrm{Hu}$ et al., 2008) and exhibit more rapid tissue regeneration potential (Leroux et al., 2010), enhanced wound-healing function (Rosova et al., 2008; Lee et al., 2009) as well as increased engraftment in vivo (Hung et al., 2007) when compared to the cells cultured under normoxic conditions. It has been demonstrated that culturing at reduced oxygen helps to maintain the multipotent and undifferentiated state of MSCs (Basciano et $a l ., 2011)$ and can prevent proliferative senescence and increase their lifespan (Tsai et al., 2011).

In this study, freshly thawed cASCs from P5, cultured under hypoxic conditions in the presence of autologous serum and exposed to two freeze-thaw cycles, were intravenously administered to two Beagle dogs. At first, only a solution containing $10 \%$ DMSO, which is found in a cell freezing medium, was intravenously injected to test its potential side-effects followed by a therapeutic dose of cASCs and a five times higher dose of cells one month later. DMSO has a half-life of $9 \mathrm{~h}$ after intravenous administration, and it is excreted as dimethylsulphide (DMS) via the kidneys, respiratory system, and bile duct system (Blythe et al., 1986). While the primary liver parameters were within normal range (ALAT, ASAT, LDH, alkaline phosphatase, total protein, and albumin) and blood count was normal, bilirubinaemia, bilirubinuria, and urobilinogenuria were found after
cASC administration. This may be due to the effect of DMSO metabolism in which DMSO transforms into DMS affecting the bile duct system or individual differences in the bile duct excretion system. Alternatively, it may also be the result of a mild haemolysis after cASC injection. However, damage to hepatocytes can be excluded due to normal liver biochemistry. Blood coagulation factors were not affected and electrocardiogram, echocardiogram, and behavioural monitoring did not show any serious deviations. None of acute reactions expected after cASC administration, such as thrombosis, were detected. Therefore, the assessment of a pulmonary first-pass effect after cASC intravenous injection allowed to eliminate the risk of pulmonary thromboembolism and demonstrated the first stage safety of cASCs.

The second stage of cASC safety was evaluated two years later by histomorphological analysis of organs and tissues to detect late changes in tissues and exclude the possibility of cASC malignisation. The most significant changes were subcapsular and subpleural inflammation foci found in lungs and kidneys. In kidneys (female) and lungs (female and male), small granulomas with eosinophilic leukocytes were observed; therefore, their parasitic origin (including Dirofilaria repens) cannot be excluded, although the dogs were regularly dewormed. In one instance, a temporary presence of Dirofilaria repens in the microflora was observed in the Beagles, but the microfilariae disappeared after the treatment.

Enhanced hyperplasia of lymphoid tissues with a mild inflammation of intestines was detected in the intestinal tract of the male dog. Soft to liquid faeces were often clinically observed in that animal, but laboratory tests did not show either parasitic or bacterial pathogens, and it is likely to be considered a dog's individual response. Sensitivity to some feed ingredient also could not be excluded.

Focal segmental fibrosis was found in kidneys, and chronic inflammation was detected in urinary bladder, prostate, urethra, kidneys, and renal pelvis of the male dog. These changes may indicate a transient bacterial infection and often occur incidentally. Also, liver microgranulomas, sclerotic glomeruli in the kidneys (both dogs), minimal inflammation in the intestines and lymphoid tissue hyperplasia (female dog) are considered to be incidental finds that are often encountered in dog sections (Sato et al., 2012).

Changes in the thymus may be due to incomplete thymic involution, which is often observed in laboratory Beagles (Sato et al., 2012), or to hyperplasia of the thymus. Both could be seen rather often in non-experimental dogs. However, the possibility that thymus hyperplasia is associated with cASC injections could not be ruled out.

Overall, the changes in tissues found in both dogs are slight and relatively non-specific. It is difficult to judge whether any of them might be a result of cASC administration. Series of chronic changes were identified, and it is theoretically possible that some of them may be related to the intra- 
venous injection of cASCs. However, part of the observed changes may be referred to as sporadic changes in laboratory Beagles used in toxicological studies (Sato et al., 2012).

Since humans and dogs share similar autoimmune diseases, e.g., rheumatoid arthritis, type 1 diabetes mellitus and dermatomyositis that could be treated using ASCs, ethically approved and naturally ill dogs could serve as ideal companion animal disease models in the future studies. It would allow to explore the therapeutic efficacy of ASCs without a need to induce the diseases artificially. ASCs could be also used for experimental treatment of dogs with such autoimmune diseases. Results obtained in canine models would provide essential information necessary for planning ASC therapy in humans.

\section{CONCLUSION}

This study showed that our specific methodology used for the preparation of ASCs and their subsequent administration protocol in a dog model are safe and do not raise any concerns about undesirable events or side effects. The safety of the methodology was especially evidenced by the ASC pulmonary first-pass effect test. Taking into account a plethora of similarities between dog and human biology, we propose that further applications of our methodology for canine disease treatment experiments might lead to a cure of analogous human diseases.

\section{ACKNOWLEDGEMENTS}

We appreciate valuable help and advice from Prof. Pauls Pumpēns, Prof. Aija Žilēviča, Prof. Alberts Auzāns, Diāna Legzdiña, Rafaels Joffe, Zita Muižniece, Māra Vasil̦evska, Jūlija Spela, Anna Veidemane, Agnis Zvaigzne, and Gulšena Eivazova during the study.

This work was supported by the grants No. 10.0014 and No. 09.1283 of the Latvian Council of Science.

\section{CONFLICTS OF INTEREST}

There are no conflicts of interest.

\section{REFERENCES}

Abdi, R., Fiorina, P., Adra, C. N., Atkinson, M., Sayegh, M. H. (2008). Immunomodulation by mesenchymal stem cells. Diabetes, 57, 1759-1767.

Anjos-Afonso, F., Siapati, E. K., Bonnet, D. (2004). In vivo contribution of murine mesenchymal stem cells into multiple cell-types under minimal damage conditions. J. Cell Sci., 117, 5655-5664.

Anonymous (2007). No. 1394/2007 of the European Parliament and of the Council of 13 November 2007 on advanced therapy medicinal products and amending directive 2001/83/EC and regulation (EC) no 726/2004. $J$. Eur. Union, 324, 121-137.

Anonymous (2014). Report from the commission to the European Parliament and the Council in accordance with article 25 of regulation (EC) no $1394 / 2007$ of the European Parliament and of the Council on advanced therapy medicinal products and amending directive 2001/83/EC and regu- lation (EC) no 726/2004. Available from:

https://publications.europa.eu/en/publication-detail/-/publication/2dc18b82-b6c8-11e3-86f9-01aa75ed71a1 (accessed 30.01.2018).

Anonymous (2015). General Secretariat of the Council to Delegations; Document number 15054/15: Personalised medicine for patients: Council conclusions. 07.12.2015. Available from:

http://data.consilium.europa.eu/doc/document/ST-15054-2015-INIT/en/pdf (accessed 30.01.2018)

Basciano, L., Nemos, C., Foliguet, B., de Isla, N., de Carvalho, M., Tran, N., Dalloul, A. (2011). Long term culture of mesenchymal stem cells in hypoxia promotes a genetic program maintaining their undifferentiated and multipotent status. BMC Cell Biol., 12, 12.

Bentzon, J. F., Stenderup, K., Hansen, F. D., Schroder, H. D., Abdallah, B. M., Jensen, T. G., Kassem, M. (2005). Tissue distribution and engraftment of human mesenchymal stem cells immortalized by human telomerase reverse transcriptase gene. Biochem. Biophys. Res. Comm., 330, 633-640.

Blythe, L. L., Craig, A. M., Christensen, J. M., Appell, L. H., Slizeski, M. L. (1986). Pharmacokinetic disposition of dimethyl sulfoxide administered intravenously to horses. Amer. J. Vet. Res., 47, 1739-1743.

Bogdanova, A., Berzins, U., Nikulshin, S., Skrastina, D., Ezerta, A., Legzdina, D., Kozlovska, T. (2014). Characterization of human adiposederived stem cells cultured in autologous serum after subsequent passaging and long term cryopreservation. J. Stem Cells, 9, 135-148.

Carrade, D. D., Borjesson, D. L. (2013). Immunomodulation by mesenchymal stem cells in veterinary species. Compar. Med., 63, 207-217.

Corcione, A., Benvenuto, F., Ferretti, E., Giunti, D., Cappiello, V., Cazzanti, F., Risso, M., Gualandi, F., Mancardi, G. L., Pistoia, V., Uccelli, A. (2006). Human mesenchymal stem cells modulate B-cell functions. Blood, 107, $367-372$.

Cyranoski, D. (2010). Korean deaths spark inquiry. Nature, 468, 485.

de Bakker, E., Van Ryssen, B., De Schauwer, C., Meyer, E. (2013). Canine mesenchymal stem cells: State of the art, perspectives as therapy for dogs and as a model for man. Vet. Quart., 33, 225-233.

De Jesus, M. M., Santiago, J. S., Trinidad, C. V., See, M. E., Semon, K. R., Fernandez, M. O., Jr., Chung, F. S. (2016). Autologous adipose-derived mesenchymal stromal cells for the treatment of Psoriasis vulgaris and psoriatic arthritis: A case report. Cell Transplant., 25, 2063-2069.

Desiderio, V., De Francesco, F., Schiraldi, C., De Rosa, A., La Gatta, A., Paino, F., d'Aquino, R., Ferraro, G. A., Tirino, V., Papaccio, G. (2013). Human $\mathrm{Ng} 2+$ adipose stem cells loaded in vivo on a new crosslinked hyaluronic acid-Lys scaffold fabricate a skeletal muscle tissue. J. Cell. Physiol., 228, 1762-1773.

Di Nicola, M., Carlo-Stella, C., Magni, M., Milanesi, M., Longoni, P. D., Matteucci, P., Grisanti, S., Gianni, A. M. (2002). Human bone marrow stromal cells suppress T-lymphocyte proliferation induced by cellular or nonspecific mitogenic stimuli. Blood, 99, 3838-3843.

Dominici, M., Le Blanc, K., Mueller, I., Slaper-Cortenbach, I., Marini, F., Krause, D., Deans, R., Keating, A., Prockop, D., Horwitz, E. (2006). Minimal criteria for defining multipotent mesenchymal stromal cells. The International Society for Cellular Therapy position statement. Cytotherapy, 8, 315--317.

Eggenhofer, E., Benseler, V., Kroemer, A., Popp, F. C., Geissler, E. K., Schlitt, H. J., Baan, C. C., Dahlke, M. H., Hoogduijn, M. J. (2012). Mesenchymal stem cells are short-lived and do not migrate beyond the lungs after intravenous infusion. Frontiers Immunol., 3, 297.

Eggenhofer, E., Luk, F., Dahlke, M. H., Hoogduijn, M. J. (2014). The life and fate of mesenchymal stem cells. Frontiers Immunol., 5, 148.

Fang, B., Li, N., Song, Y., Li, J., Zhao, R. C., Ma, Y. (2009). Cotransplantation of haploidentical mesenchymal stem cells to enhance engraftment of hematopoietic stem cells and to reduce the risk of graft failure in two children with severe aplastic anemia. Pediatric Transplant., 13, 499-502.

Fang, B., Song, Y., Liao, L., Zhang, Y., Zhao, R. C. (2007). Favorable response to human adipose tissue-derived mesenchymal stem cells in ste- 
roid-refractory acute graft-versus-host disease. Transplant. Proc., 39 3358-3362.

Fischer, U. M., Harting, M. T., Jimenez, F., Monzon-Posadas, W. O., Xue, H., Savitz, S. I., Laine, G. A., Cox, C. S., Jr. (2009). Pulmonary passage is a major obstacle for intravenous stem cell delivery: The pulmonary first-pass effect. Stem Cells Devel., 18, 683-692.

Furlani, D., Ugurlucan, M., Ong, L., Bieback, K., Pittermann, E., Westien, I., Wang, W., Yerebakan, C., Li, W., Gaebel, R., Li, R. K., Vollmar, B., Steinhoff, G., Ma, N. (2009). Is the intravascular administration of mesenchymal stem cells safe? Mesenchymal stem cells and intravital microscopy. Microvasc. Res., 77, 370-376.

Ghannam, S., Bouffi, C., Djouad, F., Jorgensen, C., Noel, D. (2010). Immunosuppression by mesenchymal stem cells: Mechanisms and clinical applications. Stem Cell Res. Ther., 1, 2.

Hall, M. N., Rosenkrantz, W. S., Hong, J. H., Griffin, C. E., Mendelsohn, C. M. (2010). Evaluation of the potential use of adipose-derived mesenchymal stromal cells in the treatment of canine atopic dermatitis: A pilot study. Vet. Ther. Res. Appl. Vet. Med., 11, E1-14.

Han, S. M., Kim, H. T., Kim, K. W., Jeon, K. O., Seo, K. W., Choi, E. W., Youn, H. Y. (2015). CTLA4 overexpressing adipose tissue-derived mesenchymal stem cell therapy in a dog with steroid-refractory pemphigus foliaceus. BMC Vet. Res., 11, 49.

Hoffman, A. M., Dow, S. W. (2016). Concise review: Stem cell trials using companion animal disease models. Stem Cells (Dayton, Ohio), 34, 1709-1729.

Honmou, O., Houkin, K., Matsunaga, T., Niitsu, Y., Ishiai, S., Onodera, R., Waxman, S. G., Kocsis, J. D. (2011). Intravenous administration of auto serum-expanded autologous mesenchymal stem cells in stroke. Brain, 134, 1790-1807.

Hu, X., Yu, S. P., Fraser, J. L., Lu, Z., Ogle, M. E., Wang, J. A., Wei, L. (2008). Transplantation of hypoxia-preconditioned mesenchymal stem cells improves infarcted heart function via enhanced survival of implanted cells and angiogenesis. J. Thor. Cardiovasc. Surg., 135, 799-808.

Hung, S. C., Pochampally, R. R., Hsu, S. C., Sanchez, C., Chen, S. C., Spees, J., Prockop, D. J. (2007). Short-term exposure of multipotent stromal cells to low oxygen increases their expression of CX3CR1 and CXCR4 and their engraftment in vivo. PloS One, 2, e416.

Ivanovic, Z. (2009). Hypoxia or in situ normoxia: The stem cell paradigm. J. Cell. Physiol., 219, 271-275.

Jung, J. W., Kwon, M., Choi, J. C., Shin, J. W., Park, I. W., Choi, B. W., Kim, J. Y. (2013). Familial occurrence of pulmonary embolism after intravenous, adipose tissue-derived stem cell therapy. Yonsei Med. J., 54, 1293-1296.

Kang, J. W., Kang, K. S., Koo, H. C., Park, J. R., Choi, E. W., Park Y. H. (2008). Soluble factors-mediated immunomodulatory effects of canine adipose tissue-derived mesenchymal stem cells. Stem Cells Devel., 17, 681-694.

Kang, M. H., Park, H. M. (2014). Evaluation of adverse reactions in dogs following intravenous mesenchymal stem cell transplantation. Acta Vet. Scand., 56, 16 .

Karagiannis, K., Proklou, A., Tsitoura, E., Lasithiotaki, I. (2017). Impaired mRNA expression of the migration related chemokine receptor CXCR4 in mesenchymal stem cells of COPD patients. Int. J. Inflam., 2017, 6089425.

Kim, M., Kim, D. I., Kim, E. K., Kim, C. W. (2017). CXCR4 overexpression in human adipose tissue-derived stem cells improves homing and engraftment in an animal limb ischemia model. Cell Transplant., 26, 191-204.

Kisiel, A. H., McDuffee, L. A., Masaoud, E., Bailey, T. R., Esparza Gonzalez, B. P., Nino-Fong, R. (2012). Isolation, characterization, and in vitro proliferation of canine mesenchymal stem cells derived from bone marrow, adipose tissue, muscle, and periosteum. Amer. J. Vet. Res., 73, 1305-1317.

Kraitchman, D. L., Tatsumi, M., Gilson, W. D., Ishimori, T., Kedziorek, D., Walczak, P., Segars, W. P., Chen, H. H., Fritzges, D., Izbudak, I., Young, R. G., Marcelino, M., Pittenger, M. F., Solaiyappan, M., Boston, R. C.,
Tsui, B. M., Wahl, R. L., Bulte, J. W. (2005). Dynamic imaging of allogeneic mesenchymal stem cells trafficking to myocardial infarction. Circulation, 112, 1451-1461.

Le Blanc, K., Tammik, L., Sundberg, B., Haynesworth, S. E., Ringden, O. (2003). Mesenchymal stem cells inhibit and stimulate mixed lymphocyte cultures and mitogenic responses independently of the major histocompatibility complex. Scand. J. Immunol., 57, 11-20.

Lee, E. Y., Xia, Y., Kim, W. S., Kim, M. H., Kim, T. H., Kim, K. J., Park, B S., Sung, J. H. (2009). Hypoxia-enhanced wound-healing function of adipose-derived stem cells: Increase in stem cell proliferation and up-regulation of VEGF and bFGF. Wound Repair Regen., 17, 540-547.

Legzdina, D., Romanauska, A., Nikulshin, S., Kozlovska, T., Berzins, U. (2016). Characterization of senescence of culture-expanded human adipose-derived mesenchymal stem cells. Int. J. Stem Cells, 9, 124-136.

Leroux, L., Descamps, B., Tojais, N. F., Seguy, B., Oses, P., Moreau, C., Daret, D., Ivanovic, Z., Boiron, J. M., Lamaziere, J.M., Dufourcq, P., Couffinhal, T., Duplaa, C. (2010). Hypoxia preconditioned mesenchymal stem cells improve vascular and skeletal muscle fiber regeneration after ischemia through a Wnt4-dependent pathway. Mol. Ther., 18, 1545-1552.

Li, Q., Zhang, A., Tao, C., Li, X., Jin, P. (2013). The role of SDF-1-CXCR4/CXCR7 axis in biological behaviors of adipose tissue-derived mesenchymal stem cells in vitro. Biochem. Biophys. Res. Comm., 441, 675-680.

Lim, J. Y., Ra, J. C., Shin, I. S., Jang, Y. H., An, H. Y., Choi, J. S., Kim, W. C., Kim, Y. M. (2013). Systemic transplantation of human adipose tissue-derived mesenchymal stem cells for the regeneration of irradiation-induced salivary gland damage. PloS One, 8, e71167.

Liu, H., Liu, S., Li, Y., Wang, X., Xue, W., Ge, G., Luo, X. (2012). The role of SDF-1-CXCR4/CXCR7 axis in the therapeutic effects of hypoxia-preconditioned mesenchymal stem cells for renal ischemia/reperfusion injury. PloS One, 7, e34608.

Lo Sicco, C., Reverberi, D., Balbi, C., Ulivi, V., Principi, E., Pascucci, L., Becherini, P., Bosco, M. C., Varesio, L., Franzin, C., Pozzobon, M., Cancedda, R., Tasso, R. (2017). Mesenchymal stem cell-derived extracellular vesicles as mediators of anti-inflammatory effects: Endorsement of macrophage polarization. Stem Cells Transl. Med., 6, 1018-1028.

Lysaght, T., Lipworth, W., Hendl, T., Kerridge, I., Lee, T.L., Munsie, M., Waldby, C., Stewart, C. (2017). The deadly business of an unregulated global stem cell industry. J. Med. Ethics, 43 (11).

Martinello, T., Bronzini, I., Maccatrozzo, L., Mollo, A., Sampaolesi, M., Mascarello, F., Decaminada, M., Patruno, M. (2011). Canine adipose-derived-mesenchymal stem cells do not lose stem features after a long-term cryopreservation. Res. Vet. Sci., 91, 18-24.

McIntosh, K. R., Frazier, T., Rowan, B. G., Gimble, J. M. (2013). Evolution and future prospects of adipose-derived immunomodulatory cell therapeutics. Expert Rev. Clin. Immunol., 9, 175-184.

Moll, G., Le Blanc, K. (2015). Engineering more efficient multipotent mesenchymal stromal (stem) cells for systemic delivery as cellular therapy. ISBT Science Series, 10, 357-365.

Muzes, G., Sipos, F. (2016). Heterogeneity of stem cells: A brief overview. Meth. Mol. biol. (Clifton, N.J.), 1516, 1-12.

Neupane, M., Chang, C.C., Kiupel, M., Yuzbasiyan-Gurkan, V. (2008). Isolation and characterization of canine adipose-derived mesenchymal stem cells. Tissue Eng. Part A, 14, 1007-1015.

O’Kell, A. L., Wasserfall, C., Catchpole, B., Davison, L. J., Hess, R. S., Kushner, J. A., Atkinson, M. A. (2017). Comparative pathogenesis of autoimmune diabetes in humans, NOD mice, and canines: Has a valuable animal model of Type 1 Diabetes been overlooked? Diabetes, 66, 1443-1452.

Prologo, J. D., Hawkins, M., Gilliland, C., Chinnadurai, R., Harkey, P., Chadid, T., Lee, Z., Brewster, L. (2016). Interventional stem cell therapy. Clin. Radiol., 71, 307-311.

Ra, J. C., Kang, S. K., Shin, I. S., Park, H. G., Joo, S. A., Kim, J. G., Kang, B.-C., Lee, Y. S., Nakama, K., Piao, M. (2011a). Stem cell treatment for patients with autoimmune disease by systemic infusion of culture-expanded 
autologous adipose tissue derived mesenchymal stem cells. J. Translat. Med., 9, 181 .

Ra, J. C., Shin, I. S., Kim, S. H., Kang, S. K., Kang, B. C., Lee, H. Y., Kim, Y. J., Jo, J. Y., Yoon, E. J., Choi, H. J. (2011b). Safety of intravenous infusion of human adipose tissue-derived mesenchymal stem cells in animals and humans. Stem Cells Devel., 20, 1297-1308.

Reich, C. M., Raabe, O., Wenisch, S., Bridger, P. S., Kramer, M., Arnhold, S. (2012). Isolation, culture and chondrogenic differentiation of canine adipose tissue- and bone marrow-derived mesenchymal stem cells-a comparative study. Vet. Res. Comm., 36, 139-148.

Rosova, I., Dao, M., Capoccia, B., Link, D., Nolta, J. A. (2008) Hypoxic preconditioning results in increased motility and improved therapeutic potential of human mesenchymal stem cells. Stem Cells (Dayton, Ohio), 26, 2173-2182.

Russell, K. A., Chow, N. H. C., Dukoff, D., Gibson, T. W. G., LaMarre, J., Betts, D. H., Koch, T. G. (2016). Characterization and immunomodulatory effects of canine adipose tissue- and bone marrow-derived mesenchymal stromal cells. PLoS One, 11, e0167442.

Sato, J., Doi, T., Wako, Y., Hamamura, M., Kanno, T., Tsuchitani, M., Narama, I. (2012). Histopathology of incidental findings in beagles used in toxicity studies. J. Toxicol. Pathol., 25, 103-134.

Shapiro, H. M., Shapiro, H. M. (2003). Practical Flow Cytometry. $4^{\text {th }}$ edn. Wiley-Liss. 736 pp.

Sparrow, R. L., Tippett, E. (2005). Discrimination of live and early apoptotic mononuclear cells by the fluorescent SYTO 16 vital dye. J. Immunol. Meth., 305, 173-187.

Spees, J. L., Gregory, C. A., Singh, H., Tucker, H. A., Peister, A., Lynch, P. J., Hsu, S. C., Smith, J., Prockop, D. J. (2004). Internalized antigens must be removed to prepare hypoimmunogenic mesenchymal stem cells for cell and gene therapy. Mol. Ther., 9, 747-756.

Stepien, A., Dabrowska, N. L., Maciagowska, M., Macoch, R. P. (2016). Clinical application of autologous adipose stem cells in patients with multiple sclerosis: Preliminary results, Mediators Inflamm., 2016, 5302120.

Sullivan, M. O., Gordon-Evans, W. J., Fredericks, L. P., Kiefer, K., Conzemius, M. G., Griffon, D. J. (2016). Comparison of mesenchymal stem cell surface markers from bone marrow aspirates and adipose stromal vascular fraction sites. Frontiers Vet. Sci., $2,82$.

Takemitsu, H., Zhao, D., Yamamoto, I., Harada, Y., Michishita, M., Arai, T. (2012). Comparison of bone marrow and adipose tissue-derived canine mesenchymal stem cells. BMC Vet. Res., 8, 150.

Tatsumi, K., Ohashi, K., Matsubara, Y., Kohori, A., Ohno, T., Kakidachi, H., Horii, A., Kanegae, K., Utoh, R., Iwata, T., Okano, T. (2013). Tissue factor triggers procoagulation in transplanted mesenchymal stem cells leading to thromboembolism. Biochem. Biophys. Res. Comm., 431, 203-209.

Tsai, C. C., Chen, Y. J., Yew, T. L., Chen, L. L., Wang, J. Y., Chiu, C. H., Hung, S. C. (2011). Hypoxia inhibits senescence and maintains mesenchymal stem cell properties through down-regulation of E2A-p21 by HIF-TWIST. Blood, 117, 459-469.

Tsuji, W., Rubin, J. P., Marra, K. G. (2014). Adipose-derived stem cells: Implications in tissue regeneration. World J. Stem Cells, 6, 312-321.

Tyndall, A., Uccelli, A. (2009). Multipotent mesenchymal stromal cells for autoimmune diseases: Teaching new dogs old tricks. Bone Marrow Transplantation, 43, 821-828.

Veriter, S., Andre, W., Aouassar, N., Poirel, H. A., Lafosse, A., Docquier, P. L., Dufrane, D. (2015). Human adipose-derived mesenchymal stem cells in Cell therapy: Safety and feasibility in different "Hospital Exemption" clinical applications. PloS One, 10, e0139566.

Vieira, N. M., Brandalise, V., Zucconi, E., Secco, M., Strauss, B. E., Zatz, M. (2010). Isolation, characterization, and differentiation potential of canine adipose-derived stem cells. Cell Transplant., 19, 279-289.

Vives, J., Carmona, G. (2015). Guide to Cell Therapy GxP: Quality Standards in the Development of Cell-Based Medicines in Non-pharmaceutical Environments. Academic Press. 266 pp.

Zuk, P. A., Zhu, M., Ashjian, P., De Ugarte, D. A., Huang, J. I., Mizuno, H., Alfonso, Z. C., Fraser, J. K., Benhaim, P., Hedrick, M. H. (2002). Human adipose tissue is a source of multipotent stem cells. Mol. Biol. Cell, 13, 4279-4295.

Zuk, P. A., Zhu, M., Mizuno, H., Huang, J., Futrell, J. W., Katz, A. J., Benhaim, P., Lorenz, H. P., Hedrick, M. H. (2001). Multilineage cells from human adipose tissue: implications for cell-based therapies. Tissue Eng., 7, $211-228$.

\section{NO SUN̦U TAUKAUDIEM IZDALĪTO CILMES ŠŪNU RAKSTUROJUMS UN IN VIVO DROŠĪBA}

Šis pētījums raksturo no suņa taukaudiem izdalītas cilmes šūnas (cASC) salīdzinājumā ar cilvēka ASCs (hASC) un pārbauda to drošumu pēc intravenozas ievadīšanas suṇa modelī. cASC tika iegūtas no diviem suṇiem un audzētas hipoksiskos apstākḷıs barotnē, kas saturēja autologo serumu. Tās bija vārpstveida šūnas, kas spēja piestiprināties pie plastmasas un ekspresēja tādus virsmas markierus kā CD73, CD90 un CD44, bet neuzrādīja CD45, CD14, HLA-DR un CD34 ekspresiju. Šīs cASC diferencējās adipogēnajā, osteogēnajā un hondrogēnajā virzienā, taču to diferenciācija par adipocītiem bija vāja. Blasttransformācijas reakcija parādīja, ka cASC būtiski samazina T šūnu proliferāciju un šì spēja ir atkarīga no šūnu devas. Intravenoza šūnu iesaldēšanas barotnes, terapeitiskās cASC devas $\left(2 \times 10^{6}\right.$ dzīvas šūnas $/ \mathrm{kg}$ ) un piecas reizes lielākas cASC devas ievadīšana suniem neradīja būtiskas blaknes. Audu histomorfoloǵiskā analīze atklāja tikai nelielas un relatīvi nespecifiskas izmaiņas, un nekādas malignizācijas pazīmes netika novērotas. Iegūtie rezultāti liecina, ka cASC ir līdzīgas hASC un drošas terapeitiskam pielietojumam. Mūsu ieviestā metodoloǵija ASC sagatavošanai ārpus rutīnas apstākḷiem, kas iekḷauj individuāli optimizētus šūnu audzēšanas apstākḷus un piedāvā riskam piemērotu ārstēšanu, var tikt izmantota personalizētai, nekavējoties pieejamai terapijai nākotnē, piemēram, miokarda infarkta vai insulta gadījumā. 